\title{
Pumping Stopped
}

National Cancer Institute

\section{Source}

National Cancer Institute. Pumping Stopped. NCI Thesaurus. Code C62859.

Unexpected /unintended cessation of pump. 